\title{
ANALISA PENERAPAN AKAD DALAM PARIWISATA SYARIAH BERDASARKAN FATWA MUI DEWAN SYARIAH NASIONAL NOMOR 108/DSN-MUI/X/2016
}

\section{Teguh Suripto}

Fakultas Agama Islam Universitas Alma Ata, Indonesia, Email: teguh_suripto@yahoo.com

\begin{abstract}
ABSTRAK
Histori Artikel

Submitted:

1 Oktober 2019

Reviewed:

15 Oktober 2019

Accepted:

1 November 2019

Published:

15 November 2019

Pada tahun 2014 terdapat 108 juta wisatawan muslim yang merepresentasikan 10 persen dari keseluruhan industri wisata. Oleh karena itu penting sekali Yogyakarta mulai mempersiapkan paket wisata syariah atau paket wisata halal. Wisata syariah dapat dipersiapkan dengan mengacu atau berpedoman pada fatwa MUI yang telah dikeluarkan sebagai pedoman bagi masyarakat untuk memahami pengertian dan pengelolaan wisata halal atau wisata syariah. Penelitian telah dilakukan menggunakan metodologi diskriptif, yang menggambarkan obyek melalui pengamatan dan penelusuran literatur yang relevan dengan obyek penelitian tersebut. Hasil dari penelitian menyimpulkan bahwa Islam memberikan pedoman atau tuntunan kepada umatnya dalam beriwisata sesuai nilai-nilai Islam, Dalam pariwisata juga telah ditentukan akad-akad yang sesuai, seperti yang tercantum dalam fatwa MUI mengenai pariwisata syariah, antara lain ijarah, ju'alah, dan wakalah bil ujrah. Pengembangan pariwisata DIY perlu melibatkan seluruh stakeholder pariwisata termasuk ulama.
\end{abstract}

Kata Kunci : Pariwisata Syariah, Akad, Fatwa MUI

\section{ANALYSIS OF APPLICATION OF AKAD IN SHARIA TOURISM BASED ON FATWA MUI DEWAN SYARIAH NASIONAL NUMBER 108/DSN-MUI/X/2016}

\begin{abstract}
In 2014 there were 108 million Muslim tourists representing 10 percent of the entire tourism industry. Therefore it is very important that Yogyakarta starts to prepare sharia tourism packages or halal tourism packages. Sharia tourism can be prepared by referring to or referring to the MUI fatwa that has been issued as a guideline for the community to understand the understanding and management of halal tourism or sharia tourism. This study will use a descriptive methodology, which describes the object through observation and literature search that is relevant to the object of the study. The results of the study concluded that Islam provides guidance or guidance to its followers in traveling in accordance with Islamic values. In accordance with tourism, appropriate agreements have been determined, as stated in the MUI fatwa on sharia tourism, including ijarah, ju'alah, and wakalah bil ujrah. The development of DIY tourism needs to involve all tourism stakeholders including scholars.
\end{abstract}

Keywords : Pariwisata Syariah, Akad, Fatwa MUI 


\section{PENDAHULUAN}

Indonesia adalah sebuah negara dengan penduduk beragama Islam terbesar, hampir $80 \%$ penduduk Indonesia adalah muslim. Potensi ini mengakibatkan Indonesia menjadi negara yang memudahkan berkembangnya bisnis atau industri syariah, salah satunya adalah industri di sektor pariwisata syariah. Menurut sebuah studi yang dilakukan oleh Master Card dan Cresent Rating, dalam Global Muslim Travel Index (GMTI), bahwa pada tahun 2014 terdapat 108 juta wisatawan muslim yang merepresentasikan 10 persen dari keseluruhan industri wisata, sedangkan segmen ini memiliki nilai pengeluaran sebesar US\$ 145 miliar. Sedangkan Indonesia merupakan salah satu negara yang masuk dalam kategori 10 besar negara tujuan organisation of Islamic Cooperation (OIC) dan Non OICdalam GMTI 2015, Indonesia berada pada rangking ke enam, setelah qatar diurutan ke lima, dan Malaysia di urutan pertama.Dengan realitas tersebut, maka Indonesia memiliki peluang besar untuk dapat mengembangkan wisata syariah ini menjadi destinasi unggulan.

Industri pariwisata syariah sebenarnya bukanlah suatu ancaman bagi industri pariwisata yang sudah ada, melainkan sebagai pelengkap dan tidak menghambat kemajuan usaha wisata yang sudah berjalan. Bahkan di beberapa negara di dunia, telah mengembangkan pariwisata syariah, diantaranya Malaysia, Thailand, Singapura, Korea, Jepang, Taiwan, dan China. Thailand memiliki sebuah lembaga The Halal Center Chulalongkorn Univercity, sebuah pusat riset yang bekerjasama dengan pemerintah Thailand dan keagamaan membuat sertifikasi dan standarisasi industri yang dilakukan secara transparan, bahkan pembiayaannya tertera dengan jelas dan transparan. Australia melalui Queensland Tourism telah mengeluarkan program pariwisata syariah pada bulan Agustus 2012, melalui kerjasama dengan hotel-hotel ternama mengadakan buka puasa bersama, menyediakan tempat sholat yang nyaman, memberikan petunjuk arah kiblat, menyediakan al qur'an di hotelhotel.
Bagaimanakah keberadaan pariwisata syariah di Indonesia? Sampai dengan saat ini penggunaan istilah syariah bagi pariwisata di Indonesia masih debatebel, label wisata syariah di Indonesia sendiri kurang mendapat persetujuan, kemenpar melalui menteri parwisata, menyampaikan bahwa penggunaan istilah syariah berkesan eksklusif dan pelarangan berbasis agama tertentu. Nama yang sempat ditawarkan oleh Menpar adalah Universal Tourism (Tim Asisten Deput litbang Kemenpar, 2015). Dengan sebutan univesal tourism tersebut terkandung nilai-nilai syariah dalam muatan paket dan kemasan wisata syariah, sehingga bisa digunakan oleh wisatawan non muslim. Sedangkan menurut MUI melalui fatwa MUI Dewan Syariah Nasional nomor 108/DSNMUI/X/2016 tentang pedoman penyelenggaraan pariwisata berdasarkan prinsip syariah disampaikan bahwa pariwisata syariah adalah pariwisata yang sesuai dengan prinsip syariah., bahkan dalam fatwa MUI tersebut, telah dijelaskan pula tentang akad-akad yang berlaku dalam industri pariwisata syariah, misalnya akad ijarah, akad wakalah bil ujrah, dan akad ju'alah. Akad-akad tersebut digunakan dalam melakukan transaksi dalam industri pariwisata. Akad ijarah digunakan antara wisatawan dengan BPWS (Biro Perjalanan Wisata Syariah), Akad ju'alah dilakukan antara BPWS dengan pemandu wisata, Akad wakalah bil ujrah digunakan antara hotel syariah dengan BPWS. Selain itu dalam fatwa MUI tersebut juga telah diberikan ketentuan terkait beberapa industri pariwisata syariah, misalnya untuk hotel syariah, wisatawan, Destinasi, ketentuan tentang spa, sauna, dan massage, ketentuan tentang Biro Perjalanan Wisata syariah, dan ketentuan pemandu wisata syariah. Dengan dasar landasan tersebut, seharusnya pariwisata syariah telah dapat berkembang secara maksimal, sehingga mampu meningkatkan pendapatan negara.

Sementara itu di Yogyakarta sebagai salah satu propinsi yang memiliki julukan kota pariwisata, sampai dengan saat ini masih terus berupaya melakukan pengembangan 
wisata halal. Dengan dibangunnya bandara internasional yang baru yaitu NYIA, sebagai pintu gerbang wisatawan, maka diharapkan akan banyak wisatawan asing yang masuk ke yogyakarta. Menurut data statistik pariwisata Yogyakarta 2018, kunjungan wisatawan mancanegara ke Indonesia, dari urutan pertama adalah Belanda sebesar 50.996 orang, disusul kemudian Malaysia sebesar 49.892 orang, selanjutnya Singapura sebesar 37.934 orang, Jepang sebesar 25.816 orang, Perancis sebesar 21.241 orang, Amerika Serikat 17.815 orang, Jerman sebesar 17.429 orang, Australia sebesar 16.798 orang, Korea selatan sebesar 14.846 orang, dan China sebesar 10.449 orang (Tim Dinpar DIY, 2018). Dari kunjungan tersebut terlihat bahwa tiga urutan terbesar wisatawan yang datang ke Indonesia adalah Belanda, Malaysia, dan Singapura. Dari ketiga negara tersebut, Malaysia dan Singapura memiliki jumlah penduduk Muslim yang cukup besar. Dengan demikian DIY termasuk propinsi yang memilki potensi kunjungan wisatawan muslim yang cukup besar. Namun permasalahannya adalah seberapa jauh kesiapan DIY menjadi kota wisata halal atau wisata syariah.

Disamping kunjungan wisatawan, DIY juga memiliki obyek wisata sebagai destinasi yang menarik, dan terdapat juga destinasi wisata yang memiliki kandungan nilai histori Islam. Sebagai contoh Masjid Gede Kauman, Masjid Shultoni Plosokuning, Masjid Pakualaman, Masjid Wonokromo Pleret Bantul, Masjid ad dorojatun Babadan Banguntapan, serta wisata alam, budaya, dan sejarah lainnya yang menarik. Semua destinasi ini jika dikemas menjadi paket wisata syariah atau wisata halal tentu akan banyak yang berminat, terutama wisatawan mancanegara. Sementara ini Yogyakarta hanya banyak mengandalkan destinasi wisatanya pada Kraton, Prambanan, dan Parangtritis.

Oleh karena itu penting sekali Yogyakarta mulai mempersiapkan paket wisata syariah atau paket wisata halal, sebagai alternatif bagi wisatawan untuk mengunjungi Yogyakarta, terutama untuk wisatawan mancanegara dari timur tengah, dan negara Islam lainnya. Wisata halal atau wisata syariah dapat dipersiapkan dengan mengacu atau berpedoman pada fatwa MUI yang telah dikeluarkan sebagai pedoman bagi masyarakat untuk memahami pengertian dan pengelolaan wisata halal atau wisata syariah. Karena pada prinsipnya wisata syariah tidak hanya berupa produk halal saja, akan tetapi juga berkaitan dengan akad-akad yang sesuai dengan ajaran dalam Islam. Bagaimana Hotel beroperasi syariah, bagaimana Travel Biro berjalan sesuai dengan syariah Islam, bagaimana perlakuan terhadap wisatawan yang sesuai dengan ajaran Islam, serta bagaimana wisatawan bersikap terhadap obyek wisata. Semua hal ini telah diatur dalam Islam, sehingga pariwisata syariah adalah kegiatan wisata yang mencerminkan nilai-nilai Islam dalam setiap aktivitasnya. Oleh karena itu pariwisata menjadi sangat penting, karena pariwisata sangat berpengaruh pada kehidupan ekonomi seorang muslim, seperti berpengaruhnya terhadap ekonomi global ataupun ekonomi Islam (Rahmi Syahriza, 2014)

Dengan latar belakang permasalahan tersebut, maka penting untuk dilakukan penelitian yang menganalisa tentang akad dalam pariwisata, seperti yang tertuang dalam fatwa MUI tentang pariwisata syariah.

Artikel ini akan memberikan manfaat bagi dunia pariwisata diantaranya adalah : Dapat menjadi literatur akademik bagi penelitian selanjutnya yang ingin mengetahui dan menganalisa pariwisata syariah. Dapat menjadi rekomendasi untuk mengembangkan strategi pengelolaan pariwisata yang berdasarkan nilai-nilai syariah, sehingga dapat diwujudkan hotel menjadi daya tarik bagi wisatawan untuk mengunjungi obyek atau destinasi wisata syariah. Dapat menjadi sumber informasi bagi para stakeholder pariwisata, untuk Menjalankan bisnis atau mengelola obyek wisata sesuai dengan nilai atau ajaran dalam Islam. Dapat menjadi sumber bacaan bagi mahasiswa untuk memahami pariwisata syariah sesuai dengan ajaran dalam Islam. 


\section{LITERATUR REVIEW \\ Pariwisata Syariah}

Di era global saat ini Pariwisata menjadi lokomotif bagi berkembangnya perekonomian suatu negara. Oleh karena itu setiap negara berlomba-lomba menata, mengembangkan, dan menawarkan obyek wisat yang menjadi unggulannya kepada seluruh masyarakat di belahan dunia. Termasuk salah satu unggulan dalam pariwisata adalah adanya pariwisata syariah. Menurut terminologi bahasa pariwisata berarti suatu aktivitas atau kegiatan perjalanan yang dilakukan untuk rekreasi atau liburan dan juga persiapan yang dilakukan untuk aktivitas ini. Seorang wisatawan atau turis adalah seseorang yang melakukan perjalanan paling tidak sejauh 80 $\mathrm{km}$, dari rumahnya dengan tujuan rekreasi (wikipedia.org, 2019). Sedangkan dalam istilah bahasa arab dengan kata "al-Siyahah, al-Rihlah, dan al-Safar (Rohi Baalbaki, 1995)

Sepanjang sejarah wisatawan muslim yang menjadi wisatawan adalah Ibnu Batuta, beliau dikenal seorang musafir yang melakukan perjalanan pertama dari afrika utara, syiria, mekkah, dan negara arab lainnya. Didalam Al Qur'an pariwisata diartikan "sara-yasiru-siru-sairan-saiyaratan" berarti berjalan,melakukan perjalanan, dari kata tersebut dijumpai kata "syaiar, munatasnya saiyarah", dengan makna yang banyak menempuh perjalanan.(Johari Arifin, 2014). Kata safara dalam Al-Qur'an memiliki beragam makna yaitu (AlAshfahaniy, 2002, dalam Rahmi, 2014) Membuka dan membersihkan debu. Menunjukkan warna seperti dalam surat alMudatsir :34. Melakukan perjalanan sebagaimana dalam surat al-Nisa : 43. Bermakna kitab seperti diungkapkan dalam surat al-Jumu'ah : 5

Sedangkan menurut Dr. Abdul Hakim Ash-Sha'idi dalam bukunya berjudul ArRihlahfi Islam. Islam membagi bepergian atau perjalanan dalam lima kelompok yaitu : Bepergian untuk mencari keselamatan, seperti hijrah keluar dari negara yang penuh haram. Bepergian untuk tujuan keagamaan seperti menuntut ilmu, pergi haji, berziarah ke tempat leluhur. Bepergian untuk kemashlatan dunia. Bepergian untuk urusan kemasyarakatan. Bepergian untuk kepentingan turisme atau kesenangan semata.

Dengan demikian menurut pandangan Islam telah diterangkan dengan jelas diperbolehkannya seseorang untuk berwisata ke berbagai penjuru dunia. Sedangkan dalam Fatwa MUI tetntang pariwisata syariah disebutkan bahwa pariwisata syariah adalah pariwisata yang sesuai dengan prinsip syariah.

Disamping itu dalam dalam pemahaman Islan pariwisata juga memiliki pengertian wisata halal, halal Syeikh Yusuf Al Qardawi dalam bukunya yang berjudul "The Lawful and Prohibited in Islam" halal didefinisikan sebagai yang diijinkandengan yang tidak ada pembatasan, dan memberlakukan hukum dari Allah dan diperbolehkan" oleh karena itu istilah halal berarti diperbolehkan menurut ajaran Islam (hukum Syariah). Halal juga merupakan salah satu dari lima tindakan (alahkam al-khamsah) yang mengkategorikan moralitas tindakan manusia dalam Islam (Mila Falma Masful, 2017). Dengan konsep pariwisata syariah, maka setiap bagian dalam pariwisata tersebut, seharusnya memiliki atau mengandung unsur halal, baik itu dalam produknya, pelayanannya, dan proses produksi jasanya.

\section{Akad Syariah}

Akad dalam pengertian Islam adalah berasal dari kata al-Aqd bentuk masdar kata 'Aqada dan jamaknya adalah al-Uqud yang berarti perjanjian (yang tercatat) atau kontrak. Sedangkan dalam Ensiklopedi Hukum Islam, bahwa kata al-Aqd berarti perikatan, perjanjian dan pemufakatan (alittifaq).

Dalam Al-Qur'an telah difirmankan oleh Allah SWT, yang atinya "Hai orang-orang yang beriman penuhilah akad-akad itu" (QS. Al Maidah : 1). Rukun akad terdiri dari tiga hal utama yaitu Aqidan adalah pihak-pihak yang akan melakukan akad, Mahal al-aqd adalah obyek akad berupa jasa atau benda berharga, Sighah adalah pernyataan resmi 
adanya transaksi. Beberapa jenis akad yang terdapat dalam Islam, diantaranya adalah : Mudharabah, adalah bentuk kerjasama antara dua atau lebih pihak dimana pemilik modal (shohibul amal) mempercayakan sejumlah nodal kepada pengelola (Mudharib) dengan suatu perjanjian di awal.

Murabahah adalah perjanjian jual beli antara bank dengan nasabah. Bank syariah membeli barang yang akan diiperlukan nasabah, kemudian menjualnya kepada nasabah sebesar harga perolehan ditambah dengan margin keuntungan antara bank syariah dengan nasabah. Salam adalah akad jual beli barang pesanan antara pembeli dan penjual dengan pembayaran dimuka dan pengiriman barang oleh penjual dibelakang. Istishna adalah akad jual beli dalam bentuk pemesanan pembuatan barang tertentudengan kriteria dan persyaratan tertentu. Ijarah adalah pemindahan hak guna (manfaat) atas suatu barang dalam waktu tertentu dengan pembayaran sewa (ujrah) tanpa diikuti dengan pemindahan kepemilikan atas barang tersebut.

Qardh adalah akad pinjaman kepada nasabah dengan ketentuan bahwa nasabah wajib mengembalikan dana yang diterimanya kepada Lembaga Keuangan Syariah (LKS) pada waktu yang telah disepakati Ar-Rahn adalah perjanjian penyerahan barang untuk menjadi agunan dari fasilitas pembayaran yang diberikan (Syiwa Awaliyah, 2018). Sedangkan akad Ju'alah adalah janji atau komitmen (iltizam) untuk memberikan imbalan (reward/'iwadh/ju'l) atas pencapaian hasil (natijah) yang ditentukan dari suatu pekerjaan. Ja'il adalah orang yang berjanji akan memberikan imbalan tertentu atas pencapaian hasil pekerjaan (natijah) yang ditentukan. Maj'ul lah adalah pihak yang melaksanakan ju'alah (fatwa MUI Nomor 62/DSN-MUI/XII,2007)

\section{METODE}

Penelitian telah dilakukan menggunakan beberapa metode pengumpulan data, yaitu metode Studi Pustaka atau literatur, yaitu suatu metode pengumpulan data dengan menggunakan sumber dari jurnal, buku,
Majalah, dan WEB Site yang relevan dan metode Observasi, yaitu metode pengunpulan data dengan melakukan pengamatan terhadap obyek penelitian melalui fenomena yang terjadi. Sedangkan metode penelitian yang digunakan adalah metode diskriptif kualitatif, yaitu menggambarkan atau mendiskripsikan obyek penelitian dengan menganalisa literatur yang diperoleh melalui studi pustaka.

\section{HASIL DAN PEMBAHASAN}

\section{Pariwisata Dalam Ajaran Islam}

Pariwisata merupakan sektor penting bagi sebuah negara dalam memperoleh sumber pendapatan, karena dengan semakin banyaknya destinasi wisata yang dimiliki dan dikunjungi oleh wisatawan, maka sumber pendapatan akan mengalir ke negara tersebut. Salah satu bentuk pariwisata yang menarik wisatawan untuk mengunjungi adalah pariwisata syariah. Pariwsata syariah adalah suatu kegiatan yang didukung dengan berbagai fasilitas dan layanan yang sesuai dengan prinsip syariah, adapun yang dimaksud dengan prinsip syariah adalah prinsip hukum Islam terkait berbagai kegiatan pariwisata berdasarkan fatwa yang dikeluarkan oleh lembaga berwenang yaitu MUI (Abdurahman Misno, 2014). Selanjutnya dalam islam juga memberikan pedoman atau tuntunan dalam beriwisata sesuai nilai-nilai Islam, diungkapkan dalam al Qur'an dengan menggunakan perintah (amr). Allah SWT menyerukan kepada seluruh umat manusia agar melakukan perjalanan yang diiringi dengan memperhatikan dan mentadabur apa yang mereka liat tersebut, dengan demikian manusia akan memperoleh rihlah jika didiringi dengan taddabur, karena taddabur akan mengingatkan mereka sebagai hamba Allah di muka bumi ini, yang harus selalu mensyukuri nikmat yang diberikan oleh Allah SWT. Didalam Islam kegiatan wisata berkaitan dengan tujuan-tujuan yang mulia, diantaranya :

Mengaitkan wisata dengan ibadah, sehingga mengharuskan adanya safar untuk 
menunaikan salah satu rukun dalam agama yaitu haji pada bulan- bulan tertentu, dan umrah. Ketika ada seseorang datang kepadanya, minta izin untuk berwisata dengan pemahaman yang lama, yaitu safar dengan kerahibanatau sekedar menyiksa diri. Nabi Muhamad SAW, memberikan petunjuk kepada maksud yang lebih tinggi atau lebih mulia dari sekedar berwisata dengan mengatakan kepadanya, "sesungguhnya wisatanya umatku adalah berjihad di jalan Allah" (HR Abu Daud 2486, dinyatakan hasan oleh Al-Albany dalam Shahih Abu Daud dan dikuatkan sanadnya oleh Al-Iraqi dalam kitab Al Takhrij Ihya Ulumudin, no. 2641) (Rahmi Syahriza, 2014).

Mengaitkan wisata dengan ilmu dan Pengetahuan, dalam permulaan Islam telah ada perjalanan sangat agung dengan tujuan mencari ilmu dan menyebarkannya. Sampai Al Khatib Al Bagdady menulis kitab yang terkenal " Ar-Rihlah Fi Thalabil Hadist" di dalamnya beliau mengumpulkan kisah orang yang melakukan perjalanan hanya untuk mendapatkan dan mencari satu hadist saja diantaranya adalah apa yang diucapkan oleh sebagian tabiin (Rahmi Syahriza, 2014). Mengaitkan wisata dengan kebaikan, didalam al qur'an sangat jelas disampaikan bahwa setiap manusia diharuskan mengamalkan kebaikan kepada semua makhluk Allah, dan dimanapun berada. Hal ini mengisyartkan kepada kita bahwa makna berwisata adalah mencintai kebaikan, keindahan dan kebersihan manusia terhadap lingkungannya, seperti di firmankan Allah dalam surat Al baqarah : 222, Allah berfirman yang artinya :"Sesungguhnya Allah menyukai orangorang yang bertaubat dan menyukai orangorang yang mensucikan diri”. Dari ayat tersebut jelas bahwa Allah ingin semua umatnya menjaga kebersihan lingkungannya, kebersihan badannya dan juga kebersihan tempat tinggalnya. Selain itu Rosululloh SAW, juga bersabda dalam hadist yang diriwayatkan HR. Baihaqi, sebagai berikut :"Agama Islam itu adalah (agama) yang bersih dan suci, maka hendaklah kamu menjaga kebersihan. Sesungguhnya tidak akan masuk surga kecuali orang- orang yang suci" (HR Baihaqi).

Mengaitkan wisata dengan menjaga lingkungan dari kerusakan, dengan menjaga lingkungan tersebut diharapkan kelestarian dan keindahan alam dapat terus dinikmati oleh semua makhluk Allah, serta dapat memberikan kedamaian dalam kehidupan manusia di muka bumi. Dalam surat Ar-Rum : 56, Allah SWT berfirman, "dan janganlah kamu berbuat kerusakan di muka bumi setelah (diciptakan) dengan baik. Berdoalah kepadaNYA dengan rasa takut dan penuh harap. Sesungguhnya rahmat Allah sangat dekat kepada orang yang berbuat kebaikan." (Ar-Rum : 56). Mengaitkan wisata dengan rasa syukur atas ciptaan Allah SWT. Hakekat perjalanan dalam berwisata adalah menikmati keindahan atau keunikan suatu tempat wisata, baik itu dalam bentuk wisata alam, misalnya gunung, laut, hutan, dan bentuk wisata buatan, misalnya taman hiburan, bioskop, dan lainnya, hendaknya diniatkan dengan mensyukuri nikmat Allah yang diberkan kepada kita. Hal ini seperti firman Allah " Tanah yang baik, tanam tanamannya tumbuh subur atas izin Allah. Dan tanah yang tidak subur tanam tanamannya hanya tumbuh merana, Demikianlah kami mengulangi tanda-tanda kebesaran (kami) bagi orang-orang yang bersyukur (Q.S Al A'Raf : 58)

Disamping itu, dalam ajaran Islam juga disampaikan bahwa dorongan Islam kepada umatnya untuk melakukan perjalanan wisata adalah untuk mendapatkan kesempatan bersenang-senang dengan cara yang sehat (Johar Arifin, 2015). Dalam riwayat Islam disampaikan bahwa mendapatkan kesenangan yang sehat dan bermanfaat bisa diraih dengan cara melakukan perjalanan dari kota ke kota atau dari negara ke negara lain. Menyaksikan ciptaan Tuhan yang indah seperti gunung, sungai yang mengalir deras, mata air yang jernih atau hutan-hutan yang hijau dan lautan yang luas, ini semua akan memberikan rasa senang dan kesegaran jiwa manusia serta menambah kekuatan iman kepada sang khaliq (Johar Arifin, 2015). Selain itu menurut Syekh Jamaludin Al- 
Qasimi, dalam kitabnya Al Mahasin alTa'wil mengatakan "perintah untuk melakukan perjalanan wisata dan menyaksikan peninggalan kaum terdahulu adalah untuk mengambil pelajarandari peninggalan tersebut. Semua ini dimaksudkan Allah agar dijadikan pelajaran oleh umat-umat berikutnya (Jamaluddin AlQasimi, dalam Johar Arifin, 2015), selanjunya firman Allah tercantum dalam Qs. Al-Ghasiyah (88) : 18-21 tentang ajuran untuk mendalami ayat-ayat kauniyah.

Islam juga memberikan pandangan tentang pariwisata syariah dari aspek muamalah sebagai wujud dari aspek kehidupan sosial, baik dari sisi budaya maupun ekonomi. Di dalam muamalah pandangan agama terhadap aktifitas sosial dan amaliahnya didasari makna kaidah yang disebut maqasid $A l$ Syariah. Menurut Ibnu Al-Qaiyim Al Jauziah syariat itu senantiasa didasarkan kepada maqasid syari' dan terwujudnya kemaslahatan masyarakat secara keseluruhan baik di dunia maupun di akhirat (Ibnu Qaiyum al-Jauzi, 1973, dalam Johar Arifin, 2015)

Pariwisata juga memberhatikan kemslahatan dan mafsadat (keburukan), sehingga pengelolaan pariwisata sesuai dengan norma agama. Dalam kaedah ushul fiqh disampaikan :"menghindari (timbulnya) keburukan (harus) diutamakan dari mengambil kebaikan". Oleh karena itu pandangan Islam dalam dunia kepariwisataan, adalah Islam akan menilai pariwisata sebagai hal yang positif, jika pariwisata tersebut memiliki tujuan yang baik, jika dilakukan dengan cara-cara yang baik, dan menilai negatif, jika pariwisata tersebut memiliki tujuan yang baik, tetapi dilakukan dengan cara-cara yang tidak baik. Islam selalu mendasarkan pandangannya atau penilaiannya berdasarkan tuntunan Al Quran dan Hadist, dan prinsip-prinsip dasar ajaran Islam. Berdasarkan prinsip-prinsip Islam tersebut, maka pengelolaan pariwisata hendaknya memiliki prinsip yang sesuai Islam, yaitu : Pengelolaan pariwisata harus memiliki arah yang jelas yaitu memperkuat keimanan dan mewujudkan pengembangan akhlak yang baik (Akhlakul Kharimah). Obyek wisata yang ditampilkan tidak mengakibatkan kerusakan lingkungan, apalagi ada unsur eksploitasi secara berlebihan. Penyelenggaraan even yang mendukung keberadaan obyek juga harus memenuhi unsur halal dan mubah untuk dilaksanakan. Sarana akomodasi diselenggarakan sesuai dengan ajaran Islam, yaitu mengutamakan syari, akhlak yang baik, dan halal. Biro perjalanan, Hotel, Restoran, Transportasi menjalankan fungsinya dengan jujur, amanah, dan ramah. Semua unsur pelaku pariwisata yaitu pemerintah, Hotel, Restoran, Biro perjalanan, Tour Guide, PHRI, ASITA, dapat menjadi media dakwah yang baik bagi wisatawan.

Beberapa pedoman penting yang dapat dijalankan untuk pariwisata syariah diantaranya, semua aktifitas bisnis pariwisata (Muamalah Madhiyah) tidak boleh mengandung unsur : Maisir (judi), Riba, dan Gharar. Disamping itu pelayanan kepada wisatawan juga mengutamakan keramahan, kesabaran, keikhlasan, dan dapat menjadi media dakwah. Pola pengembangan pariwisata syariah dapat dilakukan dengan memadukan antara ajaran Islam dengan budaya lokal, sepanjang budaya lokal tersebut tidak bertentangan dengan ajaran Islam, misalnya saja di Yogyakarta terdapat obyek wisata budaya peninggalan sejarah, baik itu sejarah kerjaan hindu maupun kerajaan Islam Mataram. Dua obyek tersebut merupakan akulturasi budaya Hindu dan Islam, dua budaya ini menghasilkan karya budaya yang dapat dinikmati oleh masyarakat, misalnya kenduri selamatan mendirikan rumah, tradisi tedak siten bagi bayi yang baru lahir, sampai dengan peninggalan bangunan bersejarah masjid pathok nagoro, petilasan kerajaan mataram Islam di bantul, dan lain sebagainya. Semua unsur budaya tersebut dapat dikemas menjadi paket wisata syariah dengan pelayanan syariah yang menarik untuk disajikan kepada wisatawan yang berkunjung di Yogyakarta. Oleh karena itu pariwisata syariah bukan hanya unsur produk halalnya saja yang dimunculkan, akan tetapi lebih luas dari itu 
bagaimana Muamalah Madhiyah dapat diterapkan di pariwisata. Seperti misalnya pola pengembangan Pariwisata Syariah di Sumatera barat, di daerah tersebut berhasil dikembangkan pariwisata syariah yang memadukan antara budaya lokal dengan budaya Islam, masyarakat disana berkeyakinan bahwa siapapun yang berkepentingan langsung maupun tidak langsung terhadap resort,memikul tanggung jawab dan kewajiban yang setara untuk bersama-sama menjunjung tinggi amanah Allah SWT dalam menjaga kesucian"kawasan terlarang" ini (Mila Falma Masful, 2017)

\section{Jenis akad dan penerapan akad tersebut dalam pariwisata syariah.}

Dalam ekonomi syariah, terdapat beberapa akad yang mengatur kegiatan ekonomi, baik kegiatan bertransaksi, kegiatan hubungan antar pelaku ekonomi, akad tersebut akan memperjelas kegiatan ekonomi yang sesuai dengan syari di dalam Islam. Akad dalam bahasa arab berarti mengikat, mengunci, atau dengan kata lain membuat perjanjian. Ulama kalangan syafiiyah memperinci akad lima yaitu, mal (harta), usaha (amal), laba (ribhu), shigat (lafadh/kalimat), dan 'aqidain (dua orang yang ber akad).

Dalam pariwisata juga telah ditentukan akad-akad yang sesuai, seperti yang tercantum dalam fatwa MUI mengenai pariwisata syariah, dalam fatwa tersebut dijelaskan fatwa yang berlaku di pariwisata antara lain ijarah, ju'alah, dan wakalah bil ujrah. Akad tersebut dipakai untuk mengatur muamalah. Menurut Hadist Nabi Shallalahu alaihi wassalam beberapa prinsip dalam bermuamalah, antara lain "Barang siapa melepaskan dari seorang muslim suatu kesulitan di dunia, Allah akan melepaskan kesulitan darinya pada hari kiamat; dan Allah senantiasa menolong hambanya selama ia suka menolong saudaranya"(HR Muslim dari Abu Hurairah). Selain Hadist dari Rosulluloh, kaidah fiqih juga mengatur dalam brmuamalah, "Pada dasarnya segala bentuk muamalah boleh dilakukan kecuali ada dalil yang mengharamkannya”. Pendapat Ibnu Qudamah dalam Al Mughni VIII/323 "Kebutuhan masyarakat memerlukan adanya ju'alah; sebab pekerjaan(untuk mencapai tujuan)terkadang tidak jelas (bentuk dan masa pelaksanaannya), seperti mengembalikan budak yang hilang, hewan yang hilang, dan sebagainya. Untuk pekerjaan seperti ini tidak sah dilakukan akad ijarah (sewa/pengupahan) padahal (orang/pemiliknya) agar kedua barang yang hilang tersebut kembali, sementara itu, ia tidak menemukan orang yang mau membantu mengembalikannya secara suka rela (tanpa imbalan) oleh karena itu, kebutuhan masyarakat mendorong agar akad ju'alah untuk keperluan itu dibolehkan sekalipun (bentuk dan masa pelaksanaan) pekerjaan tersebut tidak jelas".

Dengan dasar hadist dan kaidah fiqih tersebut, maka dikeluarkanlah ketentuan oleh MUI untuk muamalah dibidang pelayanan jasa pariwisata yaitu melalui akad Ju'alah. Ketentuan dalam akad Ju'alah di sampaikan sebagai berikut : Pihak ja'il harus memiliki kecakapan hukum dan kewenangan (muthlaq al-tasharruf) untuk melakukan akad. Obyek ju'alah(mahal al-aqd/maj'ul'alaih) harus berupa pekerjaanyang tidak dilarang oleh syariah, serta tidak menimbulkan akibat yang dilarang. Hasil pekerjaan (natijah) sebagaimana dimaksud harus jelas dan diketahui oleh para pihak pada saat penawaran. Imbalan ju'alah(reward/'iwadh/ju'l) harus ditentukan besarannya oleh ja'il dan diketahui oleh para pihak pada saat penawaran. Tidak boleh ada syarat imbalan diberikan di muka (sebelum pelaksanaan obyek ju'alah)

Dari akad ju'alah tersebut jelas sekali Islam meberikan tuntunan dalam bermuamalah, agar sesuai dengan syariah Islam. Pariwisata sebagai sektor yang bergerak di bidang pelayanan jasa, semestinya menggunakan akad ju'alah dalam bermuamalah. Seperti misalnya Hotel, Restoran, Biro perjalanan, semua pelaku pariwisata tersebut harus memahami akad ju'alah tersebut. Mengenai ketentuan akad ju'alah dalam muamalah di 
bidang akomodasi, dapat kami sampaikan dalam tabel sebagai berikut :

Tabel. 1.

Penerapan akad Ju'alah di akomodasi (Hotel,Restoran,BP,Transport)

\begin{tabular}{|c|c|c|c|c|c|}
\hline \multirow[b]{2}{*}{ No } & \multirow[b]{2}{*}{ Ketentuan Akad Ju'alah } & \multicolumn{4}{|c|}{ Muamalah Akomodasi } \\
\hline & & Hotel & Restoran & $\begin{array}{c}\text { Biro } \\
\text { Perjalanan }\end{array}$ & Transportasi \\
\hline & $\begin{array}{l}\text { Pihak ja'il harus memiliki } \\
\text { kecakapan hukum dan } \\
\text { kewenangan (muthlaq al- } \\
\text { tasharruf) untuk melakukan } \\
\text { akad. }\end{array}$ & $\sqrt{ }$ & $\sqrt{ }$ & $\sqrt{ }$ & $\sqrt{ }$ \\
\hline & $\begin{array}{l}\text { Obyek ju'alah (mahal al- } \\
\text { aqd/maj'ul'alaih) harus } \\
\text { berupa pekerjaan yang } \\
\text { tidak dilarang oleh syariah, } \\
\text { serta tidak menimbulkan } \\
\text { akibat yang dilarang. }\end{array}$ & $\begin{array}{l}\text { Masih terdapat } \\
\text { hotel yang } \\
\text { tidak } \\
\text { mempertanyak } \\
\text { an identitas } \\
\text { bagi tamu yang } \\
\text { menginap } \\
\text { berpasangan } \\
\text { Masih terdapat } \\
\text { hotel yang } \\
\text { menyediakan } \\
\text { minuman } \\
\text { alkohol } \\
\text { (khamar) yang } \\
\text { dilarang dalam } \\
\text { agama Islam } \\
\text { Masih terdapat } \\
\text { hotel yang } \\
\text { menyediakan } \\
\text { hiburan malam } \\
\text { (klab Malam) }\end{array}$ & $\begin{array}{l}\text { Masih } \\
\text { terdapat } \\
\text { restoran yang } \\
\text { kurang } \\
\text { memperhatik } \\
\text { an } \\
\text { kebersihan, } \\
\text { terutama di } \\
\text { dapur, di } \\
\text { tempat cuci } \\
\text { piring, dan di } \\
\text { tempat } \\
\text { sampah. }\end{array}$ & $\sqrt{ }$ & $\sqrt{ }$ \\
\hline & $\begin{array}{l}\text { Hasil pekerjaan (natijah) } \\
\text { sebagaimana dimaksud } \\
\text { harus jelas dan diketahui } \\
\text { oleh para pihak pada saat } \\
\text { penawaran. }\end{array}$ & $\sqrt{ }$ & $\sqrt{ }$ & $\sqrt{ }$ & $\sqrt{ }$ \\
\hline & $\begin{array}{l}\text { Imbalan } \\
\text { ju'alah(reward/'iwadh/ju'l) } \\
\text { harus ditentukan } \\
\text { besarannya oleh ja'il dan } \\
\text { diketahui oleh para pihak } \\
\text { pada saat penawaran }\end{array}$ & $\sqrt{ }$ & $\sqrt{ }$ & $\sqrt{ }$ & $\sqrt{ }$ \\
\hline & $\begin{array}{l}\text { Tidak boleh ada syarat } \\
\text { imbalan diberikan di muka } \\
\text { (sebelum pelaksanaan } \\
\text { obyek ju'alah) }\end{array}$ & $\begin{array}{l}\text { Masih terdapat } \\
\text { hotel yang } \\
\text { mensyaratkan } \\
\text { uang DP (uang } \\
\text { muka) untuk } \\
\text { boking room }\end{array}$ & $\begin{array}{l}\text { Masih } \\
\text { terdapat } \\
\text { restoran yang } \\
\text { mengharuska } \\
\mathrm{n} \text { DP (uang } \\
\text { muka) untuk } \\
\text { pemesanan } \\
\text { restoran }\end{array}$ & $\begin{array}{l}\text { Masih } \\
\text { terdapat } \\
\text { Biro } \\
\text { Perjalanan } \\
\text { yang } \\
\text { mensyaratk } \\
\text { an DP } \\
\text { (uang } \\
\text { muka) } \\
\text { untuk } \\
\text { pemesanan } \\
\text { paket } \\
\text { wisata oleh } \\
\text { konsumen }\end{array}$ & $\begin{array}{l}\text { Masih } \\
\text { terdapat } \\
\text { perusahaan } \\
\text { Bus } \\
\text { Pariwisata } \\
\text { yang } \\
\text { mensyaratk } \\
\text { an DP } \\
\text { (uang } \\
\text { muka) } \\
\text { untuk } \\
\text { pemesanan } \\
\text { Bus } \\
\text { pariwisata }\end{array}$ \\
\hline
\end{tabular}

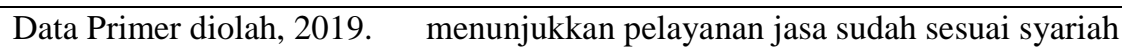


Dari tabel tersebut nampak bahwa jasa akomodasi di pariwisata masih banyak muamalah yang dilakukan tidak sesuai dengan syariah Islam. Terutama pada dua ketentuan dalam akad ju'alah, yaitu Obyek ju'alah (mahal al-aqd/maj'ul'alaih) harus berupa pekerjaan yang tidak dilarang oleh syariah, serta tidak menimbulkan akibat yang dilarang dan Tidak boleh ada syarat imbalan diberikan di muka (sebelum pelaksanaan obyek ju'alah). Dengan demikian perlu dilakukan pembinaan dan pengawasan yang continue agar penerapan akad ju'alah ini berjalan dengan baik sesuai dengan ketentuan yang berlaku atau sesuai rukun yang disyaratkan, sehingga akan terwujud pariwisata syariah sesuai dengan fatwa MUI, yang menyebutkan bahwa pariwisata syariah adalah pariwisata yang sesuai dengan prinsip syariah. Prinsip syariah yang terkandung dalam pariwisata, menurut fatwa MUI adalah : Terhindar dari kemusyrikan, kemaksiatan, kemafsadatan,tabdzir.israf, dan kemunkaran. Menciptakan kemaslahatan dan kemanfaatan baik secara material maupun spiritual.

Selain akad ju'alah, dalam pariwisata syariah juga diterapkan akad ijarah dan akad wakalah bil ujrah. Akad ijarah muncul dalam tuntunan Islam karena adanya hikmah dari ijarah, diantara hikmah tersebut adalah sesungguhnya tidak setiap orang memiliki kendaraan, tempat tinggal, pelayan dan selainnya, sedangkan ia membutuhkan semua itu namun tidak mampu membelinya, maka ijarah (sewa menyewa) diperbolehkan karena itu (Habib Hasan bin Ahmad Al-Kaaf, Taqirat as Sadidah, Yaman, Dar al-mirats, an-Nabawi, 2013). Akad ijarah dilegalkan di dalam syariat berdasarkan nash Al-Qur'an, Hadist dan Ijma ulama sebagaimana disampaikan oleh Syekh Zakaria al-Anshari, Asna Al-Mathalib, 2003Allah SWT, berfirman : "kemudian jika mereka menyusukan (anak-anak)mu untukmu maka berikanlah kepada mereka upahnya"(QS Aththalaq, 6). Ayat ini menunjukan tentang akad ijarah, sebab dalam ayat tersebut mengandung sebuah bentuk kalimat perintah, dan perintah di dalam ushul fiqh menunjukkan wajib. Upah hanya bisa diwajibkan / ditetapkan oleh akad ). Sehingga ayat inisecara pasti diarahkan pada menyusui yang disertai dengan akad (ijarah) (Habib Hasan bin Ahmad Al-Kaaf, Taqrirat asSadidah, Yaman, Dar al-Mirats an-Nabawi, 2013).

Selain Firman Allah SWT, di dalam sebuah Hadist juga disebutkan "Sesungguhnya baginda Nabi SAWmelarang muzara'ah dan memerintahkan muajjarah (akad sewa), beliau bersabda,'Tidak apa-apa melakukan muajjarah"(HR Muslim).

Ijarah secara bahasa memiliki arti nama sebuah upah. Sedangkan secara istilah syariat adalah akad (transaksi terhadap kemanfaatan yang maqshudah, maklum, bisa untuk diserahkan dan mubah dengan 'iwadl(upah) yang maklum (Syekh an-Nawawi Banten, Nihayatuz Zain, Songgopuro- Indonesia, alHaramain, hal. : 257). Dengan pengertian tersebut dapat dipahami bahwa ijarah adalah akad yang memiliki prinsip dasar sewa menyewa. Dalam Pariwisata Syariah, maka akad ijarah ini dapat dilakukan diantaran antara pihak Hotel dengan wisatawan, atau juga antara pihak Biro perjalanan Syariah dengan wisatawan. Dengan konsep ijarah ini, maka kedua belah pihak yaitu pihak wisatawan dan hotel, harus memahami rukun sahnya akad ijarah. Adapun ruku ijarah ada lima hal, yaitu : Shigat (kalimat yang digunakan dalam transaksi), seperti, misalnya "saya menyewakan kamar ini selama dua hari dengan upah/biaya lima ratus ribu rupiah". Dan pihak penyewa/wisatawan menjawab, "saya terima". Kata-kata tersebut perlu diucapkan sedemikian rupa, karena kalimat ini menjadi syarat sahnya rukun tersebut agar sesuai syariat. Dengan demikian jika tidak terdapat ucapan kalimat tersebut, maka transaksi tersebut menjadi tidak sah atau tidak memenuhi akad ijarah. Ujrah/upah/ongkos/biaya, Ujrah dalam akad ijarah harus diketahui secara jelas baik dengan langsung dilihat ataupun disebutkan kriterianya secara lengkap, misalnya menyebutkan "lima ratus ribu rupiah", Biasanya pihak hotel akan memberikan biaya 
sewa atau room rate yang sudah tertera dalam bentuk tulisan ataupun diucapkan kembali oleh front office ketika bertemu dengan penyewa (wisatawan). Manfaat, dalam hal manfaat, maka transaksi yang dilakukan harus mutaqawwamah (bernilai secara syariat), maklum, mampu dirasakan oleh penyewa, manfaat yang dirasakan penyewa bukan berbentuk barang. Dalam muamalah di hotel, manfaat yang diperoleh penyewa (wisatawan) adalah kenyamanan, karena kamar dan perlengkapannya tersedia dengan baik, oleh karena itu jika erdapat kerusakan dari salah satu bagian kamar harus segera diperbaiki kembali sebelum disewakan. Sehingga wisatawan (penyewa) tidak kecewa dengan pelayanan kamar yang disewa. Jika muncul kekecewaan atau ketidak puasan, sebenarnya hal ini telah menyalahi syarat sahnya akad ijarah di hotel tersebut. Mukri/mu'jir (pihak yang menyewakan), terdapat pihak yang menyewakan barang atau jasa yang dapat bermanfaat bagi penyewa. Syarat sahnya rukun ini adlah pihak penyewa sudah baligh, berakal, tidak terpaksa. Muktari/Musta'jir (pihak yang menyewa) pihak yang menyewa merupan individu atau perorangan yang memerlukan manfaat dari barang atau jasa yang akan disewa. Syarat sahnya rukun ini sama dengan penyewa, yaitu harus sudah baligh, berakal, tidak terpaksa

Dengan ketentuan akad ijarah tersebut, semua transaksi atau mumalah dalam pariwisata seharusnya menyesuaikan ketentuan tersebut. Pihak yang seharusnya memperhatikan ketentuan atau rukun dalam akad adalah pemerintah, Hotel, Biro Perjalanan, Tour Guide, Organisasi pariwisata : PHRI, ASITA, dan Masyarakat. Dengan memperhatikan ketentuan akad tersebut, akan dapat disusun strategi pengembangan Pariwisata Syariah.

Di DIY sendiri saat ini pemahaman pariwisata syariah baru sebatas wisata halal, belum sampai dengan pariwisata dalam arti Pariwisata Syariah yang menggunakan ketentuan atau prinsip-prinsip syariah.

\section{SIMPULAN}

Dari hasil analisa yang telah dilakukan, maka diperoleh kesimpulan bahwa Islam memberikan pedoman atau tuntunan kepada umatnya dalam beriwisata sesuai nilai-nilai Islam, diungkapkan dalam al Qur'an dengan menggunakan perintah (amr). Allah SWT menyerukan kepada seluruh umat manusia agar melakukan perjalanan yang diiringi dengan memperhatikan dan mentadabur apa yang mereka liat tersebut, dengan demikian manusia akan memperoleh rihlah jika didiringi dengan taddabur, karena taddabur akan mengingatkan mereka sebagai hamba Allah di muka bumi ini, yang harus selalu mensyukuri nikmat yang diberikan oleh Allah SWT.

Berdasarkan prinsip-prinsip Islam, pengelolaan pariwisata hendaknya memiliki prinsip yang sesuai Islam, yaitu : Pengelolaan pariwisata harus memiliki arah yang jelas yaitu memperkuat keimanan dan mewujudkan pengembangan akhlak yang baik (Akhlakul Kharimah), Obyek wisata yang ditampilkan tidak mengakibatkan kerusakan lingkungan, apalagi ada unsur eksploitasi secara berlebihan, Penyelenggaraan even yang mendukung keberadaan obyek juga harus memenuhi unsur halal dan mubah untuk dilaksanakan, Sarana akomodasi diselenggarakan sesuai dengan ajaran Islam, Biro perjalanan, Hotel, Restoran, Transportasi menjalankan fungsinya dengan jujur, amanah, dan ramah, Semua unsur pelaku pariwisata yaitu pemerintah, Hotel, Restoran, Biro perjalanan, Tour Guide, PHRI, ASITA, dapat menjadi media dakwah yang baik bagi wisatawan.

Dalam pariwisata juga telah ditentukan akad-akad yang sesuai, seperti yang tercantum dalam fatwa MUI mengenai pariwisata syariah, dalam fatwa tersebut dijelaskan fatwa yang berlaku di pariwisata antara lain ijarah, ju'alah, dan wakalah bil ujrah. Akad tersebut dipakai untuk mengatur muamalah. Prinsip syariah yang terkandung dalam pariwisata, menurut fatwa MUI adalah : Terhindar dari kemusyrikan, kemaksiatan, kemafsadatan,tabdzir.israf, dan kemunkaran, kemudian Mampu menciptakan 
kemaslahatan dan kemanfaatan baik secara material maupun spiritual. Pengembangan pariwisata DIY yang berdasarkan pada pariwisata syariah perlu dibuat strategi yang baik, yang melibatkan seluruh stakeholder pariwisata termasuk didalamnya para ulama.

\section{REFERENSI}

Rahmi Syahriza. (2014). Pariwisata Berbasis Syariah (Telaah Makna Kata Sara dan Derivasinya Dalam Al Qur'an), Jurnal Human Falah, 1(2)

Misno, A. (2018). Analisis Praktik Pariwisata Syariah Perspektif Hukum Ekonomi Syariah. Ad Deenar: Jurnal Ekonomi dan Bisnis Islam, 2(02), 135-155.

Awaliyah, S. Analisis pelaksanaan akad pembiayaan Murabahah pada BMT Bersama Kita Berkah (BKB) dan BMT At-Taqwa Pinang (Bachelor's thesis, Jakarta: Fakultas Syariah Dan Hukum UIN Syarif Hidayatullah).

Johar Arifin. (2015). Wawasan Al-Quran dan Sunnah Tentang Pariwisata. An-Nur, 4 (2)

Mila Falma Masful. (2017). Pariwisata Syariah : Suatu Konsep Kepercayaan Dan Nilai Budaya Lokal Di Daerah Pedalaman Pilubang, Payakumbuh, Sumatera Barat, The Messenger, 9(1).

Ibnu Qaiyum al-Jauzi. (1973). I'lam alMuwaqqi'in an Rabbi Al-Alamin. Beirut: Dar.jail

Habib Hasan bin Ahmad Al-Kaaf. (2013). Taqirat as Sadidah. Yaman: Dar almirats an-Nabawi

Fatwa MUI Dewan Syariah Nasional Nomor 108/DSN-MUI/X/2016

Fatwa MUI Nomor 62/DSN-MUI/XII/2007

Syekh Zakaria al-Anshari. (2003). Asna AlMathalib. Dar al-Fikr
Habib Hasan bin Ahmad Al-Kaaf. (2013). Taqrirat as-Sadidah. Yaman: Dar alMirats an-Nabawi.

Syekh an-Nawawi Banten. (1995). Nihayatuz Zain, Songgopuro: AlHaramain

Rohi Baalbaki. Al-Mawrid A Modern Arabic English Diktionary. Beirut: Dar al-Ilm Al Amalayin

Peter Salim. (1990). The Contemporary English-Indonesia Dictionary. Jakarta,

Musanef. (1990). Manajemen Usaha Pariwisata. Jakarta.

Afzalur Rahman. (1995). Doktrin Ekonomi Islam. Yogyakarta : Dana Bakti Wakaf.

https://islam.nu.or.id , diakses Rabu 30 Oktober 2019.

\section{PROFIL PENULIS}

Teguh Suripto, Pendidikan S2, Magister Manajemen, UII, Fakultas Agama Islam Universitas Alma Ata Yogyakarta, Bidang ilmu Manajemen, peminatan penelitian, Manajemen SDI (Sumber Daya Insani), Ekonomi Islam, Keuangan, perbankan, dan pariwisata syariah. Beberapa karya publikasi tercantum dalam Google Scholar.

Id scholar

https://scholar.google.co.id/citations?user=jXejz JYAAAAJ\&hl=id\&oi=ao 